\title{
Short Communication: New record of a primitive brachiopod, Lingula sp. in Lubuk Damar, Indonesia
}

\author{
ANANINGTYAS S. DARMARINI ${ }^{1, \vartheta}$, YUSLI WARDIATNO ${ }^{2, \bullet \bullet}$, TRI PRARTONO ${ }^{3}$, KADARWAN SOEWARDI ${ }^{2}$ \\ ${ }^{1}$ Doctoral Program in Aquatic Resources Management, Graduate School, Institut Pertanian Bogor. Jl. Raya Darmaga, Kampus IPB Darmaga, Bogor \\ 16680, West Java, Indonesia. `email: ananingtyas.s@gmail.com \\ ${ }^{2}$ Department of Aquatic Resources Management, Faculty of Fisheries and Marine Science, Institut Pertanian Bogor. Jl. Raya Darmaga, Kampus IPB \\ Darmaga, Bogor 16680, West Java, Indonesia. Tel./fax.: +62-251-8622932, `^email: yusli@ipb.ac.id \\ ${ }^{3}$ Department of Marine Sciences and Technology, Faculty of Fisheries and Marine Sciences, Institut Pertanian Bogor. Jalan Raya Darmaga, Kampus IPB \\ Darmaga, Bogor 16680, West Java, Indonesia.
}

Manuscript received: 3 May 2017. Revision accepted: 10 September 2017.

\begin{abstract}
Darmarini AS, Wardiatno Y, Prartono T, Soewardi K. 2017. Short Communication: New record of primitive brachiopod, Lingula sp. in mangrove ecosystem of Lubuk Damar, Aceh Tamiang, Indonesia. Biodiversitas 18: 1438-1444.. This study reports the occurrence of the primitive brachiopod, Lingula in mangrove ecosystem as a new record in Indonesia. Specimens were collected from the mangrove sediment at a depth of between the sediment surface and $20 \mathrm{~cm}$ beneath. . Lingula has a glossy shell and oval-ovate shell shape. The color of shell is brownish or greenish. In posterior a point where pedicle occurs is found. The pedicle is a prolongation of the body like an anchor, with varying length, rough, hard and striped texture. Pedicle has soft transparent layer and the edges are covered by the substrate. The inside body of Lingula, there is a lophophore, which is the characteristic of this species The total length of the brachiopod ranges from 3-122 mm. The texture of habitat consists of $39.67 \%$ sand, $50.95 \%$ silt, and $11.45 \%$ clay.
\end{abstract}

Keywords: Benthos, living fossil, Malacca Strait, marine biodiversity, soft sediment

\section{INTRODUCTION}

As an ecosystem, mangrove has been revealed to play ecological function as the center of marine biodiversity by supplying habitat for various organisms (Robertsen and Alongi 1992; Field et al. 1998; Wei-dong et al. 2003; Lee et al. 2014). For Indonesia, recent studies related to marine biodiversity have been focused mainly on the occurrence of edible marine invertebrate species, such as lobsters (e.g. Wardiatno et al. 2016a,b,c; Wahyudin et al. 2016; 2017a,b), hippoid crabs (e.g. Wardiatno 2015a,b; Mashar et al. 2014, 2015; Ardika et al. 2015). Information on the occurrence and distribution of non-edible marine organisms such as brachiopods are limited.

Brachiopoda are components significant of the early Cambrian marine faunas (Carlson 2016) and was initially included in the class of mollusk, which was then at the end of the 19 century was removed from the mollusk group (Emig 2008). Hutchins et al. (2003) mention grouping this fauna an exclusively marine group of lophophorate animals. They are called "inarticulated" because their shells lack articulation. Nonarticulate lampshells are also known as inarticulated brachiopods.

Brachiopoda is one phylum of Lophophorates (Pechenik, 2010) and the lophophore, an essential organ of the Brachiopoda (Zhang et al. 2003). Grouping Lophophorates be based animals take possession of a lophophore (Carlson 2016) and as it related to a way of eating that is using lophophore (Emig 1992; Samanta et al. 2014a, b; Carlson 2016), but is morphologically similar to the mollusk with two shells (Sundaram and Deshmukh 2011; Samanta et al. 2014). Aditionally, the brachiopoda are differentiated from the mollusk because their shells have anteroposterior symmetry. One common genus of brachiopods is Lingula and received appellation as a living fossil (Mudjiono and Suparman 1992; Emig 2003). According to Emig (1997), various types of inarticulate brachiopods spread over coastal waters at bathyal zone until abyssal and are found many in the intertidal zone.

The area of study in Lubuk Damar Aceh Tamiang is located along the coast of Malacca Strait with about $\pm 3 \mathrm{~km}$ beach length. The dominant vegetation is real mangrove vegetation consisting of several species such as Sonneratia sp., Bruguiera sexangula, Scyphiphora hydrophyllaceae, Avicennia alba, and Rizophora stylosa. The study was aimed to report the occurrence of Lingula sp. in a mangrove ecosystem in Province Aceh as a new record of Indonesia.

\section{MATERIALS AND METHODS}

Lingula sp. specimens were collected from mangrove ecosystem in Lubuk Damar, Aceh Tamiang, Province Aceh, Indonesia (Figure 1) on January 2017 during low tide at three stations. Sampling was carried out by using core with the area $0.0133 \mathrm{~m}^{2}$ at 300 sampling points and 74 individuals were obtained from 0-20 cm sediment depth. 
Collected specimens were stored in $70 \%$ ethanol after being fixed in $10 \%$ formaldehyde and sorting. Laboratory works were conducted in Biomicro Laboratory, Department of Aquatic Resources Management, Faculty of Fisheries and Marine, Bogor Agricultural University, West Java, Indonesia. Substrate analysis was conducted in Soil Laboratory, Faculty of Agriculture, University of Syiah Kuala, Banda Aceh, Indonesia. Morphological picture of the specimens was taken by the dinolite Pro 2 and macro camera of Canon Power Shot D30. Description of the specimens was based on morphology descriptions by Emig (2003), Lee and Campbell (1987), and Yugan et al. (1982).

\section{RESULTS AND DISCUSSION}

\section{Systematics}

Phylum Brachiopoda Duméril 1806; subphylum linguliformea Williams, Carlson, Brunton, Holmer \&
Popov, 1996; Class Lingulata Gorjansky and Popov 1985; Order Lingulida Waagen 1885; Superfamily Linguladea Menke 1828; Family Lingulidae Menke 1828; Genus Lingula Bruguière, 1797; Species Lingula sp. (Lee and Campbell 1987) (see Figure 2).

\section{Description and biology}

Shell shape is oval-ovate with a glossy shell. Its different size on dorsal and ventral valve Lingula (Figure 2.D) is representing the dissimilar color of the shells, brownish or greenish (Figure 2.A, D, H). In posterior a point where pedicle occurs is found (Figure 2.G). The pedicle is a prolongation of the body like anchor. Pedicle length varies with striped texture, rough and hard, the colors a light brown to creamy. Pedicle has a sort of a transparent layer (cuticle) and the top part wrapped by the substrate. The sample was found to have two types of pedicle that are stubby and elongated.

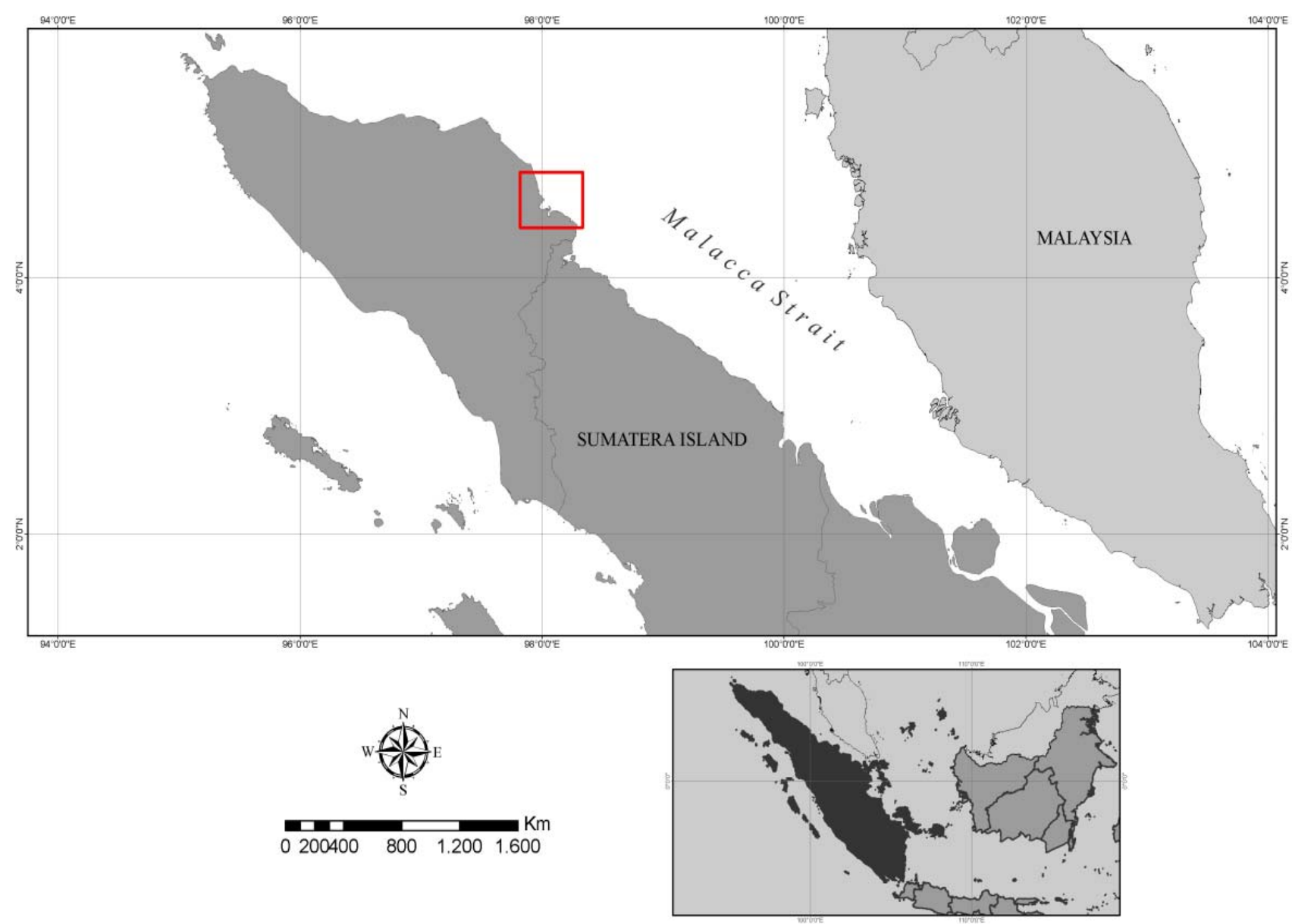

Figure 1. Research location showing the collection site of the brachiopod in the mangrove ecosystem of Lubuk Damar, Aceh Tamiang, Province Aceh-Indonesia. The red square indicates the sampling site 
In each valve has a mantle with chaeta throughout shell (Figure 2.A, H). On the anterior have chaeta a longer, functioning as an inhalant and exhalant pseudo siphon (Figure 2.H). In the sampling locations small size Lingula was found too (Figure 2.C) and chetae on juvenile is evident. The inside of the body is lophophore which is the distinctiveness of this species (Figure 2.B, E). In this study, 74 individuals of Lingula sp. were obtained, and the total length, shell length, width of a shell and pedicle length ranged from 1-122 $\mathrm{mm}, 1-39 \mathrm{~mm}, 0.2-19 \mathrm{~mm}$ and 2-99 $\mathrm{mm}$, respectively. While the weight ranged between 0.0001-6.543 g.

\section{Shell}

The size of Lingula sp. in the mangrove ecosystem of Lubuk Damar, Aceh was very diverse and bigger (3 mm$122 \mathrm{~mm}$ ), if compared with the size of Lingula found in other studies, e.g. 22.5 mm-38.5 mm (Emig 1984), 45 mm$58 \mathrm{~mm}$ (Sundaram and Deshmukh 2011), $27.5 \mathrm{~mm}$ (Hutchins et al. 2003), and $24.84 \pm 2.98 \mathrm{~mm}$ (Printrakoon et al. 2014). Shells of Lingula discovered in the mangrove ecosystem mostly had a light to dark green color (Figure 2.A, H) as in Lingula anatina reported from Subarnarekha estuaries, India (Mitra and Pattanayak 2013), but few specimens showed light brown to greenish color; similar to those found in New Caledonia (Bitner 2010) and in Ratnagiri, Maharashtra, India (Sundaram and Deshmukh 2011). Shell color distinction is probably an indication of species and environmental conditions. Observations also showed that the shell consists of two distinct parts. The anterior valve widens and posteriorly narrows which culminate in the appearance of the pedicle. The shape of shell reveal is oblong-elongate, (Figure 2.A, H) and smooth surface and Lingula sp. shells are thin and fragile, the shell divide by a dorsal and ventral valve. The ventral valve is more taper than dorsal on the posterior part. Clarke and Wheeler (1915) found that the brachiopod fell into two chemically distinct groups; one is calcareous and the other is highly phosphatic.

Emig (1979, 1984) and Samantha et al. (2014) explored the characteristics of the shell of Lingula anatina in West Bengal-Odisha coast, India, and they found their specimens had two dissimilar valves which emerge to be oblongovate, elongate, bilaterally symmetrical, endowed with parallel lateral margins, sharp beaks, and straight edges. Emig (2003) pursuant to genus Lingula characteristic from Sumatra is shell lengthen oval or subrectangular in broad outline, lateral margins subparallel, anterior margin amply spherical to lank.

Surface of the two valves was mostly found to be smooth but indicating growing process lines (Emig 1978, 1979; Hutchins et al. 2003). The outer of shell depicts flimsy growth lines (Figure 2.H). These shells have a ventral and a dorsal valve. Anterior valves have setae, two inhalant and one exhalant pseudo siphon (Emig 2003). Lingula has three low-siphonal ribs extend from beak to anterior margin of the shell (Emig 1979; Hutchins et al. 2003). Inhalant-exhalant pseudosiphon is shown in Figure $2 \mathrm{H}$.

\section{Pedicle}

All of the Lingula sp. in the study site had longer pedicle size (1-2 times and more) than the shell length. The pedicle length on location is $2 \mathrm{~mm}-99 \mathrm{~mm}$. Some juvenile sample length of the pedicle more than 3 times of the shell and some few completely lost of a pedicle. The length of pedicle size was found to be one and a half until 2 times the shell length similar (Emig 1978; 1979). The color of the pedicle is creamy to whitish (Figure 2.F) and substantially similar as described in Emig (1984). The pedicle described is fleshy in L. anatina (Emig 1979; 1984).

During the observation, some Lingula sp. position showed the pedicle on the bottom and shell upstairs in their habitat. This evidence is similar to the common findings that Lingula is a vertically digging brachiopod in soft sediments with shell position at the top of their burrows (Emig 1997, 2003; Hutchins et al. 2003). Yugan et al. (1991) mentioned that the pedicle of extant lingulids was composed of a deltoidal section banded to the pedicle valve, a cylindrical primary trunk, and a desolate bulb-like end anchored by a mucous secretion to the bottom of the burrow. The isolated bulb of the pedicle (foot like base of the organism) is firmly anchored into the substrate at the bottom of the burrow and is bestead by a mass of sand and organic particles take hold of together by sticky mucus. The pedicle of brachiopods is described attachment of generally accomplished tool of a stalk (Pechenik 2010), a stalk-like structure appearing between the two valves of most brachiopod, make easier attachment to a tough substrate but not for hard substrate (Carlson 2016).

\section{Lophophore}

Lophophore is a characteristic of Lingula (Figure 2.E, $\mathrm{B})$, and is described as muscle endowed spiral feeding structure of ciliated tentacles around the mouth (Samantha et al. (2014a). The position of lophophore is on the anterior valve and/or on the open out shell. The shape is like a snail's dwelling, in white and has a tentacle at the edges (Figure 3.A, B). It is composed of two, right and left (Figure 2.E, 3.A). Lophophore consists of two long arms the circle to form a spiral (Figure 3.A), the detail part of lophophore (Figure 3.B). Emig (1976) showed lophophore as oval shaped round the mouth with a single line of tentacles, therefore the functions may be associated to feeding, respiratory, and protection. Emig (1976, 1992) stated that the lophophore had increasingly advantage than just being considered as a feeding mechanism absorbing alimentary particles and soluble nutrients. Its primary function is a water flow model that also acts as a respiratory organ. 


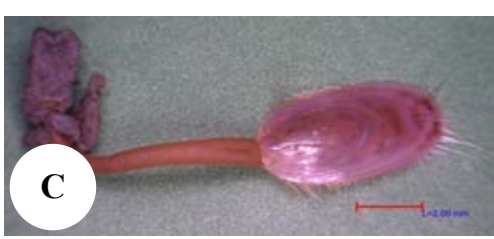

Lingula sp. juvenile

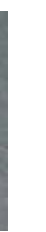

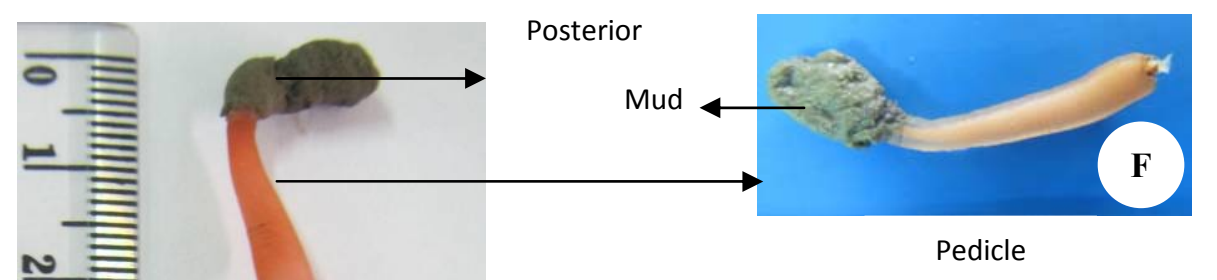

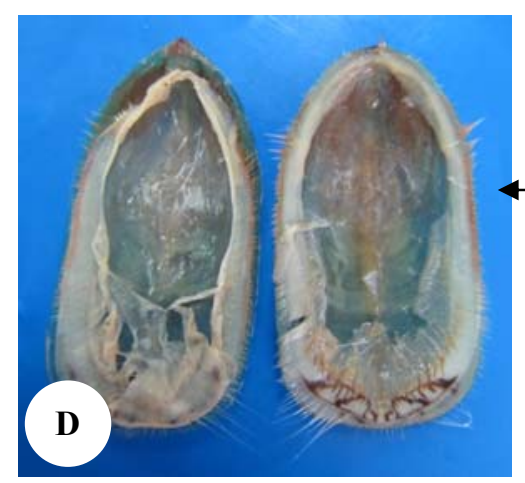

Lophophore tentacle 4

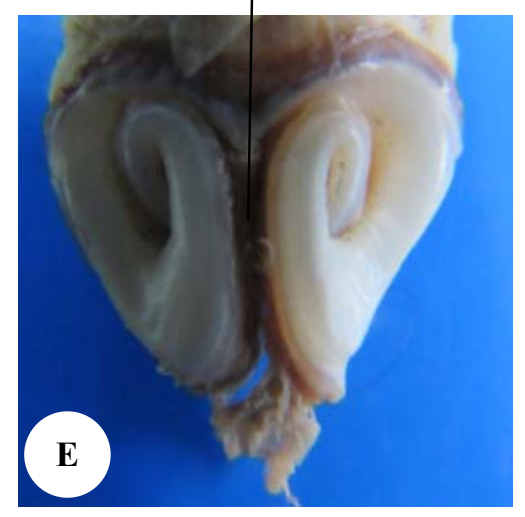

Lophophore
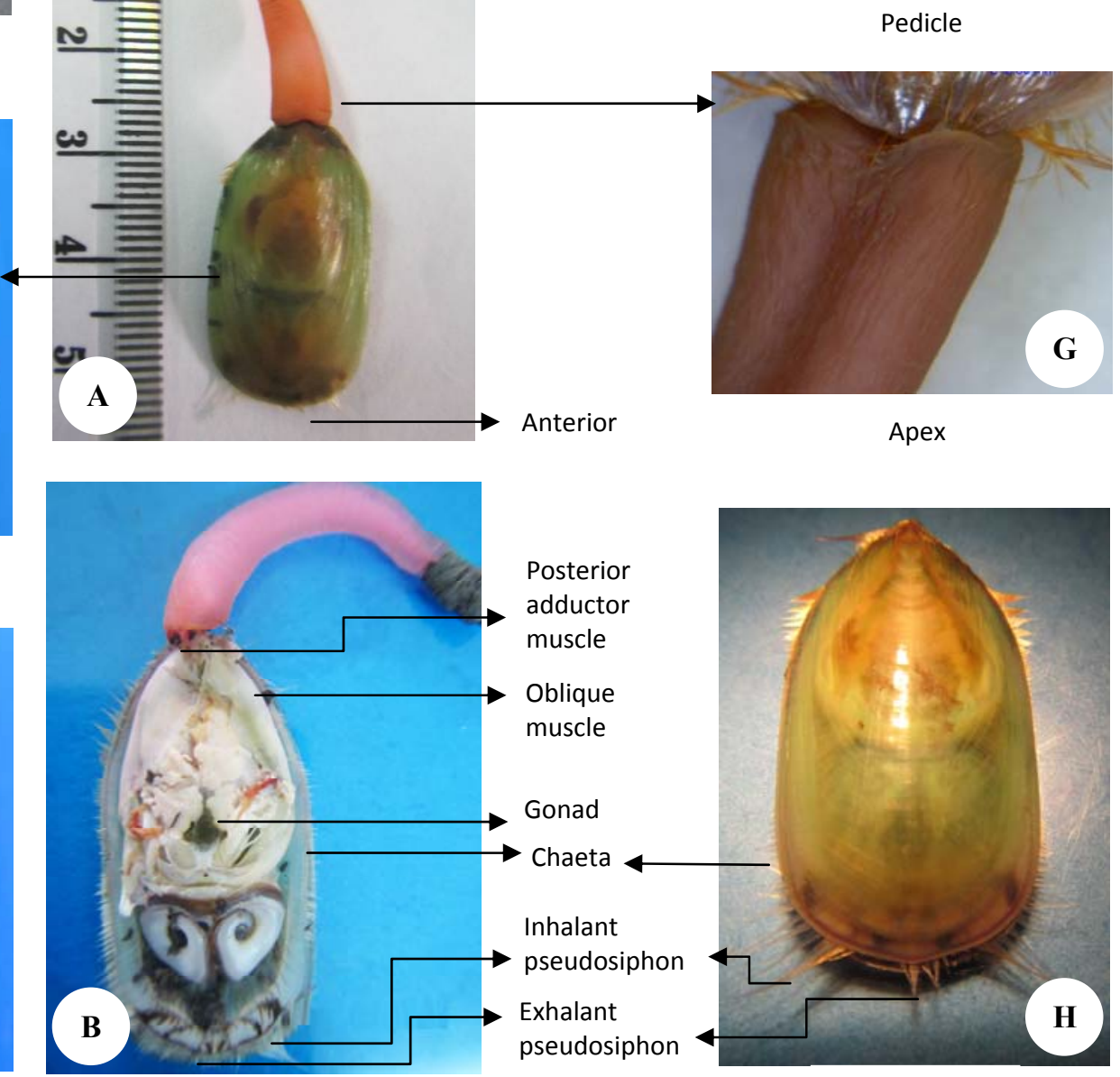

Valve

Figure 2. Morphology and anatomy of Lingula sp. collected from mangrove ecosystem in Lubuk Damar, Aceh Tamiang, Province Aceh, Indonesia. A. Body of Lingula, B. Lingula dissection, C. Juvenile, D. Valve, E. Lophophore, F. Pedicle, G. Apex, H. Shell.

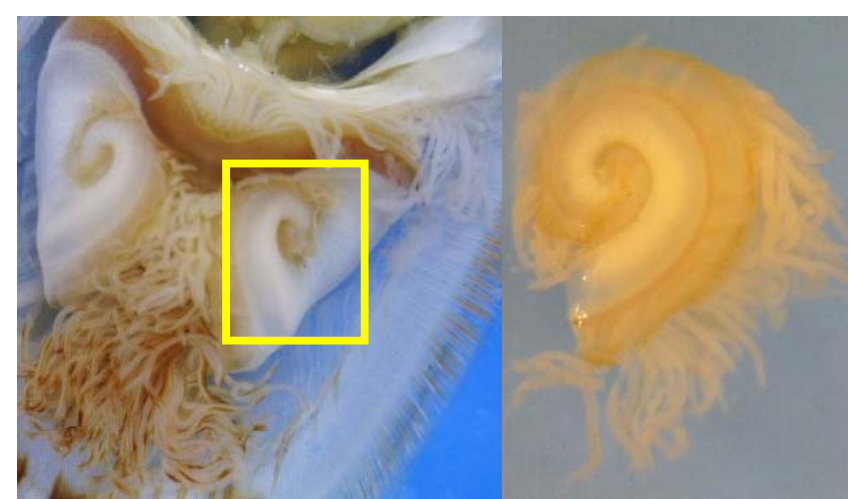

$\mathbf{A}$

B

Figure 3. Lophophore. A. Lophophore coiling, B. The coiling part of lophophore
The lophophore is an organ of two arms that endure ciliated tentacles get used to filter feeding and respiration (Carlson 2016). Lophophore is characterized by the presence of muscle crease helical with ciliated tentacles (Samanta et al. 2014a), the function of cilia (tiny hair-like structures) produce a unidirectional current of water through the mantle cavity, extracting oxygen and food particles and transporting them to the mouth (Carlson 2016). According to LaBarbera (1981) the lophophore establishes a perpetual, laminar water flow, induced by rows of lateral cilia on the tentacles. Their movement draws water through the tight cleft between tentacles. There is no internal mixing and no recirculation of filtered exhalant current. Gametes and cesspool products are discarded from the mantle cavity by the same process (Carlson 2016). The spirolophe is characteristic of all alive inarticulate (Emig 1992; Hutchins et al. 2003). 


\section{Habitat}

Observations conducted in areas of study acquired Lingula sp. of the distance from the highest tide-lowest tide was $0-500 \mathrm{~m}$, from the mangrove canopy area until the beach. Substrate texture in location was muddy with $39.67 \%$ sand, $50.95 \%$ silt and $11.45 \%$ clay. Habitat of Lingula was reported with evenly density present on intertidal areas (Emig and Hammod 1981; Bitner et al. 2012; Samanta et al. 2014), which is partially exposed in middle intertidal muddy area during low tide. Superfamily Linguloidea was reported to share an infaunal way of life (Emig1984, 2003), and were found in sandy loam regions (Samanta et al. 2015). The variance found in this so that could be found on the substrate of silt up to coral (Savazzi 1991), in shallow waters by a depth of $20 \mathrm{~m}$ or more (Samanta et al. 2014).

The similar condition to the habitat of Lingula sp. in Subarnarekha India is that the substrate in most cases was soft muddy area, but black soil (decomposed) and sand mixed mud were believed to be preferential for the living. Juvenile's bed was established in fine soft mud (Mitra and Pattanayak 2013). On Fangchenggang mangrove in China Lingula occurred from areas with fine sand (>68\%) with sediment particles on sandy loam and loamy sand (Printrakoon et al. 2014). In accordance with Hutchins et al. (2003), Lingulidae is exclusively infaunal (living in the sediment at the bottom of the ocean) in soft substrates from the intertidal zone.

In the study area, some other macrozoobenthos were also discovered, such as polychaetes (Glycera, Maldane, Pista, Pistella, Sternapsis, Onuphis, etc.), sipunculans, pelecypods (Tellina, Siliqua, Anadara, Gastrana, etc.), gastropods (Solen, Cepridula, Dentalium), crustaceans (Pagurus, Uca, Scylla, Penaeus, Alpheus), and many more (Darmarini 2017; unpublished data). This finding is similar with Mitra and Pattanayak (2013). There is probably indirect and direct relationships in habitat among those benthic animals with the brachiopod. Goto (2014) revealed a symbiotic relationship between the Lingula anatina and Koreamya setouchiensis. This mollusk embedded on the anterior part of the shell, perhaps to make use of water flow created by the host for filter feeding, estimation this bivalve may prefer to use exhalant by Lingula.

\section{Feeding ecology and diet}

Feeding habit of Lingula based on gut content analysis indicated the presence flake of mangrove leaves, planktonic materials, and detritus in the gut (Samanta et al. 2015). According to Hutchins et al. (2003) the food items of brachiopods include phytoplankton as diatom, superficial meiobenthos, colloidal organic matter. Therefore, the brachiopod can be included in suspension feeder (Emig 1984; Hutchins et al. 2003; Samanta et al. 2015; Temereva and Tsitrin 2015).

\section{Distribution}

Brachiopods live in all oceans (Emig 1997; Emig et al. 2013), and are greatly disparted geographically at depths ranging from intertidal down to more than $5000 \mathrm{~m}$ (Emig et al. 2013). They are is distributed considerably in Indo-West
Pacific area (Emig 1997). Lingula has a widely distribution in Asia, Australia, Europe, Africa (Williams et al. 2000; Mitra and Pattanayak 2013), such as in Ambon, Indonesia (Jackson and Stiasny 1937), Singapore Island (Chuang 1961), Hokkaido Japan (Hayasaka and Hatai 1956), Mutsu Bay, Northern Japan (Emig 1984), Korea (Park et al. 2000; Hong et al. 2007), mangrove area in Ratnagiri Maharashtra, India (Sundaram and Deshmuk 2011), estuary Subarnarekha (Mitra and Pattanayak 2013), Thailand (Printrakoon and Kamlung-ek 2013), north-east coast of India (Samanta et al. 2014), China seas (Ricardson et al. 1989), Fangchenggang mangrove, China (Printrakoon et al. 2014), Nhatrang Bay, Vietnam (Temereva and Tsitrin 2015), Kaneohe Bay, Oahu, Hawaii, USA (Hunter et al. 2008), Atlantic (Williams et al 2000), Spain (MarquesAliaga et al. 1999), France (Emig et al. 2007), South Germany (Bitner et al. 2009), New Zealand (Allan. 1936), Australia (Kenchington and Hammod 1977), New Caledonia, New Zealand (Bitner 2010), Madagascar (Emig 1977), Western Indian Ocean (Bitner and Logan 2016).

\section{ACKNOWLEDGEMENTS}

This paper is a part of a doctoral study of the first author. The first author is thankful to Department of Aquatic Resources Management, Faculty of Fisheries and Marine Sciences Bogor Agricultural University, for supporting laboratory. This study is funded by BPPDN Scholarship from Ministry of Research, Technology and Higher Education of the Republic of Indonesia. Constructive comments of two reviewers to improve the earlier MS are appreciated.

\section{REFERENCES}

Allan RS. 1936. New records of the genus Lingula (Brachiopoda) from Tertiary Strata in New Zealand. Trans R Soc B Biol Sci 65: 383-385.

Ardika PU, Farajallah A, Wardiatno Y. 2015. First Record of Hippa adactyla (Fabricius, 1787; Crustacea, Anomura, Hippidae) from Indonesian waters. Trop Life Sci Res 26 (2): 105-110.

Bitner MA. 2010. Biodiversity of shallow-water brachiopods from New Caledonia, SW Pacific, with a description of a new species. Sci Mar 74 (4): 643-657.

Bitner MA, Logan A. 2016. Recent Brachiopoda from the MozambiqueMadagascar area, western Indian Ocean. Zoosystema 38 (1): 1-37.

Bitner MA, Warszawa, Schneider S, Munchen. 2009. The Upper Burdigalian (Ottnangian) brachiopod fauna from the northern coast of the Upper Marine Molasse Sea in Bavaria, Southern Germany. N Jb Geol Palaont Abh 254 (1-2): 117-133.

Bitner MA, Dulai A, Kocsis L, Muller PM. 2012. Lingula dregeri (Brachiopoda) from the Middle Miocene of Hungary. Ann Soc Geol Pol 82: 39-43.

Bruguière JG. 1797. Tableau Encyclopédique et Méthodique des trois Règnes de la Nature: vers, coquilles, mollusques et polypesdivers. Panckoucke, Paris.

Carlson SJ. 2016. The evolution of brachiopoda. Annu Rev Earth Planet Sci 44: 409-438.

Chuang SH.1961.groeth of the postlarval shell in Lingula unguis (L). (Brachiopoda). Department of zoology, University of Malaya Singapore. Proc Zool Soc Lond 37: 199-212.

Clarke FW and Wheeler WC. 1915. The composition of brachiopod shells. United States Geological Survey, Washington DC.

Dumeril AMC. 1806. Zoologie analytique au method naturelle de classification des animaux. Allais. Paris. 
Emig CC. 1976. Le Lophophore-structure significative des Lophophorates (Brachiopodes, Bryozoaires, Phoronidiens). Zool Scr 5 (1-4): 133137.

Emig CC, Hammod LS. 1981. On the status of Lingula tumidula Reeve, L.adamsi Dall and L. shantungensis Hatai (Brachiopoda, Inarculata). Bull Mar Sci 31 (1): 37-45.

Emig CC, Bitner MA, Alvarez F. 2013. Phylum brachiopoda. Zootaxa 3703 (1): 075-078. DOI: 10.11646/zootaxa.3703.1.15

Emig CC. 1977. Lingula murphiana Reeve (Brachiopoda), récoltée á Madagascar. Bull Mus Hist Nat Paris ser 3. 446 (Zool 309): 401-410.

Emig CC. 1978. A redescription of the inarculate brachiopod Lingula reevii Davidson. Pac Sci 32 (1): 31-34.

Emig CC. 1979. Three species of Lingula from the Queensland coast. Mem Qd Mus 19 (3): 381-391.

Emig CC. 1984. Lingula anatina Lamarck from Mutsu Bay, northern Japan. Bull Mar Biol Stn Asamushi 17 (4): 171-176.

Emig CC. 1992. Functional disposition of lophophore in living brachiopoda. Lethaia 25: 291-301.

Emig CC.1997. Ecology of inarticulate brachiopod. In: Kaesler RL (ed.) Treatise on invertebrate paleontology. Part H, Brachiopoda revised, Vol.1, Geological Society of America, Boulder and University of Kansan Press, Lawrence.

Emig CC. 2003. Proof that Lingula (Brachiopoda) is not a living-fossil, and emended diagnoses of the Family Lingulidae.-Carnets de Géologie/Notebooks on Geology, Maintenon, Letter 2003/01 (CG2003 L01 CCE).

Emig CC. 2008. On the history of the names Lingula, anatina, and on the confusion of the forms assigned them among the Brachiopoda. Carnets de Géologie / Notebooks on Geology, Brest, Article 2008/08 (CG2008_A08).

Emig CC, Bitner M.A, Cahuzac B. 2007. First record of Lingula (Brachiopoda) from the Miocene of France, with a diagnosis of $L$. dregeri. C R Palevol (6): 261-267. DOI: 10.1016/j.crpv.2007.02.002.

Field CB, Osborn JG, Hoffman LL, Polsenberg JF, Ackerly DD, Berry JA, Bjorkman O, Held A, Matson PA, Mooney HA. 1998. Mangrove diversity and ecosystem function. Global Ecol Biogr 7: 3-14.

Gorjansky VY, Popov LE. 1985. Morfologiya, sistematicheskoe polozhenie i proiskhozhdenie bezzamkovykh brakhiopod s karbonatnoj rakovinoj. [The morphology, systematic position, and origin of inarticulate brachiopods with carbonate shells]. Paleontologicheskii Zhurnal 3: 3-13.

Goto R, Ishikawa H, Hamamura Y, Sato S, Kato M. 2014. Evolution of simbiosis with Lingula (Brachiopoda) in the bivalve superfamily Galeommatoidea (heterodonta), with description of a new species of Koreamnya. J Molluscan Stud 80 (2) 148-160.

Hayasaka I, Hatai K. 1956. A new species of Lingula from Hokkaido, Japan. Trans Pro Palaeont Soc Japan. N.S. No 23: 219-220.

Hong J, Yamashita H, Sato SI. 2007. The Saemangeum reclamation project in South Korea threatens to extinguish an unique mollusk, ecosymbiotic bivalve species attached to the shell of Lingula anatina. Plankton Benthos Res 2 (1): 70-75.

Hunter CL, Krause E, Fitzpatrick J, Kennedy J. 2008. Current and historic distribution and abundance of the inarculated brachiopod, Lingulareevii Davidson (1880) in Kaneohe Bay, Oahu, Hawaii, USA. Mar Biol 155 (2): 205-210.

Hutchins M, Craig SF, Thoney DA, Schlager N. 2003. Grzimek’s Anima Life Encyclopedia, second edition. Volume 2, Protostomes. Farmington Hills, MI: Gale Group.

Jackson JW, Stiasny G. 1937. The brachiopoda of the Siboga Expedition. Siboga Expeditie. E.J. Brill, Leiden.

Kenchington RA, Hammod LS. 1977. Population structure, growth and distribution of Lingula anatina (Brachiopoda) in Queensland, Australia. J ZoolLond 184: 63-81.

LaBarbera. 1981. Water flow patterns in and around three species of articulate brachiopods. J Exp Mar Biol Ecol. 55: 185-206.

Lee DE, Camphell JD. 1987. Cenozoic records of the genus Lingula (Brachiopoda: Inarticulata) in New Zealand. J R Soc N Z 17 (1): 1730.

Lee SY, Primavera JH, Dahdouh-Guebas F, McKee K, Bosire JO, Cannicci S, Diele K, Fromard F, Koedam N, Marchand C, Mendelssohn I, Mukherjee N, Record S. 2014. Ecological role and services of tropical mangrove ecosystems: a reassessment. Global Ecol Biogeogr 23: 726-743.

Marquez-Aliaga A, Emig CC, Brito JM. 1999. Triassic Lingulidae brachiopods from the Iberian range (Spain). Geobios 32 (6): 815-821.
MasharA, Wardiatno Y, Boer M, Butet NA, Farajallah A. 2014. Diversity and abundance of sand crabs on the south coast of Central Java. Ilmu Kelautan 19 (4): 226-232 [Indonesian]

Mashar A, Wardiatno Y, Boer M, Butet NA, Farajallah A, Ardika PU. 2015. First record of Albunea symmysta (Crustacea: Decapoda: Albuneidae) from Sumatra and Java, Indonesia. AACL Bioflux 8 (4): 611-615.

Menke CT. 1828. Synopsis methodica molluscorum generum omnium et specieru mearum, quae in museo Menkeano adservantur; cum synonymia critica et novarum specierum diagnosibus. Uslar G., Pyrmonti, Uslar.

Mitra S, Pattayak JG. 2013. Studies on Lingula anatina (Brachiopoda: Inarculata) in Subarnarekha estuary, Odisha with special reference to habitat and population. Rec Zool Surv India 113 (3): 49-53.

Mudjiono, Suparman S. 1992. Study of lamp shell, phylum Brachiopoda. Oseana 17: 159-166. [Indonesian]

Pachenik JA. 2010. Biology of the invertebrates. Sixth edition. McGrawHill Education. 606 p.

Park KY, Oh CW, Hong SY. 2000. Population dynamics of an inarticulate brachiopod Lingula unguis on the intertidal flats of Kunsan, Korea. J Marine Biol Assoc UK 80 (3): 429-435.

Printrakoon C, Kamlung-ek A. 2013. Socioeconomic study and economic value of living fossil, Lingula sp. in mangrove ecosystem in Trat Province, Thailand. Chin J Pop Res Environ 11 (3): 187-199.

Printrakoon C, Kamlung-ek A, Fan H. 2014. Possible use of Lingula sp. (Phylum Brachiopoda) as a dissemination strategy to promote sustainable development in Fangchenggang mangrove, China. Chin J Pop Res Environ 13: 269-277.

Ricardson JR, Stewart IR, Xixing L. 1989. Brachiopods from China Seas. Chin. J. Oceanol. Limnol 7 (3): 211-213.

Robertsen AI, Alongi DM. 1992. Tropical mangrove ecosystem, Washington, DC: A G U pp. 63-100.

Samanta S, Choudhury A, Chakraborty SS. 2014a. New record of a primitive brachiopod benthic fauna from the North-East coast of India. Int J Curr Res Aca Rev 2 (3): 70-73.

Samanta S, Choudhury A, Chakraborty SS. 2014b. Morpho-anatomical study of Lingula anatina Lamarck, 1801 from West Bengal-Odisha coast, India. J Mar Biol Ass India 56 (2): 26-33.

Samanta S, Choudhury A, Chakraborty SS. 2015. Eco-biology of a precambrian intertidal benthic brachiopod, Lingula anatina from the confluence of Subarnarekha estuary with Bay of Bengal, India. J Mar Biol Ass India 57 (1): 41-46.

Savazzi E. 1991. Burrowing in inarculate brachiopod Lingula anatina. Palaeogeogr Palaeoclimatol Palaeoecol 85: 101-106.

Sundaram S, Deshmukh VD. 2011. Record of inarculate brachiopoda, Lingula sp. from mangrove areas in Ratnagiri, Maharashtra and its unusual commercial exploitation. Mar Fish Information Service T\&E Ser 207: 1-2.

Temereva EN, Tsitrin EB. 2015. Modern data on the innervation of the lophophore in Lingula anatina) brachiopoda) support the monophyly of the lophophore. PloS ONE 10 (4): 1-29. DOI: 10.1371/journal.pone.0123040.

Waagen W. 1885. Salt range fossils. Vol. I, part 4. Products-limestone fossils, Brachiopoda. Mem Geol Surv India Palaeo Indica, Series 13 (5): 729-770.

Wahyudin RA, Hakim AA, Boer M, Farajallah A, Wardiatno Y. 2016. New records of Panulirus femoristriga von Martens, 1872 (Crustacea Achelata Palinuridae) from Celebes and Seram Islands, Indonesia. Biodiversitas 7 (4): 901-906.

Wahyudin RA, Hakim AA, Qonita Y, Boer M, Farajallah A, Mashar A, Wardiatno Y. 2017a. Lobster diversity of Palabuhanratu Bay, South Java, Indonesia with new distribution record of Panulirus ornatus, $P$. polyphagus and Parribacus antarcticus. AACL Bioflux 10 (2): 308327.

Wahyudin RA, Wardiatno Y, Boer M, Farajallah A, Hakim AA. 2017b. Short communication: a new distribution record of the mud-spiny lobster, Panulirus polyphagus (Herbst, 1793) (Crustacea, Achelata, Palinuridae) in Mayalibit Bay, West Papua, Indonesia. Biodiversitas 18 (2): 780-783.

Wardiatno Y, Ardika PU, Farajallah A, Mashar A, Ismail. 2015a. The mole crab Hippa marmorata (Hombron et Jacquinot, 1846) (Crustacea Anomura Hippidae): a first record from Indonesian waters. Biodiversitas 6 (2): 517-520.

Wardiatno Y, Ardika PU, Farajallah A, Butet NA, Mashar A, Kamal MM, Renjaan EA, Sarong MA. 2015b. Biodiversity of Indonesian sand 
crabs (Crustacea, Anomura, Hippidae) and assessment of their phylogenetic relationships. AACL Bioflux 8 (2): 224-235.

Wardiatno Y, Hakim AA, Mashar A, Butet NA, Adrianto L, Farajallah A 2016a. First record of Puerulus mesodontus Chan, Ma \& Chu, 2013 (Crustacea, Decapoda, Achelata, Palinuridae) from south of Java, Indonesia. Biodivers Data J 7 (4): e8069. DOI: 10.3897/BDJ.

Wardiatno Y, Hakim AA., Mashar A, Butet NA, Adrianto L. 2016b. Two newly recorded species of the lobster family Scyllaridae (Thenus indicus and Scyllarides haanii) from South of Java, Indonesia. Hayati J Biosci 23: 101-105.

Wardiatno Y, Hakim AA, Mashar A, Butet NA, Adrianto L, Farajallah A. 2016c. On the presence of the Andaman lobster, Metanephrops andamanicus (Wood-Mason, 1891) (Crustacea Astacidea Nephropidae) in Palabuhanratu Bay (S-Java, Indonesia). Biodiversitas 7 (1): $17-20$
Wei-dong $\mathrm{H}$, Jin-keL, Xiu-Ling $\mathrm{H}$, Ying-Ya C, Fu-liang Y, Li-qiang $\mathrm{X}$, Ning Y. 2003. Shellfish and fish biodiversity of mangrove ecosystems in Leizhou Peninsula, China. J Coast Dev 7 (1): 21-29.

Williams A, Carlson S, Brunton CHC, Holmer LE, Popov LE.1996. A supra-ordinal classification of the Brachiopoda. Philos Trans. R. Soc. Lond. B. Biol. Sci 351: 1171-1193

Williams A, Cohen BL, Cusak M, Long SL. 2000. Provenance of Atlantic lingulids brachiopods. Paleontology 43 (6): 999-1018.

Yugan J, Xianguang H, Huayu W. 1993. Lower Cambrian pediculate Lingulateds from Yunnan China. J Paleontol 67 (5): 788-798.

Zhang X, Hou X, Emig CC. 2003. Evidence of lophophore diversity in early Cambrian Brachiopoda. The Royal Society. Biology Letters. Proc R Soc Lond B (Suppl.) 270, S65-S68. 